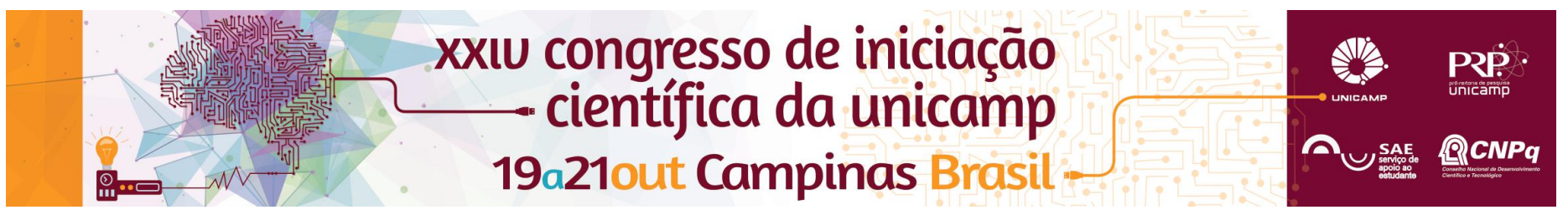

\title{
Modelos para Aumento da Eficiência da Movimentação de Cargas em um Pátio Portuário através da Representação por Regras e Algoritmo Genético.
}

\section{Ana C. A. Ferrari*, Anibal T. Azevedo.}

\section{Resumo}

Num pátio portuário, os contêineres são colocados em pilhas verticais localizadas em diversas seções. $\mathrm{O}$ acesso aos contêineres é feito somente através do topo da pilha. Um pátio portuário que permite a movimentação de contêineres com destino para vários portos, pode necessitar de muitas operações de remanejamento. Esses remanejamentos possuem custo e despendem tempo, contudo alguns deles podem ser evitados através de um planejamento eficiente. Assim são apresentadas regras de carregamento e descarregamento que combinadas ao Algoritmo Genético, um método heurístico de resolução, garante uma melhor geração de soluções factíveis.

\section{Palavras-chave:}

Algoritmo Genético, patio-portuário, movimentação de cargas.

\section{Introdução}

A eficiência de um pátio portuário está fortemente relacionada com as movimentações de cargas nele envolvidas, uma vez que estas podem determinar os gastos, tanto financeiros quanto temporais.

Para melhor organizar as operações de carregamento e descarregamento, ou seja, reduzir o número de remanejamento dos contêineres, propõe-se um algoritmo genético combinado com a representação por regras.

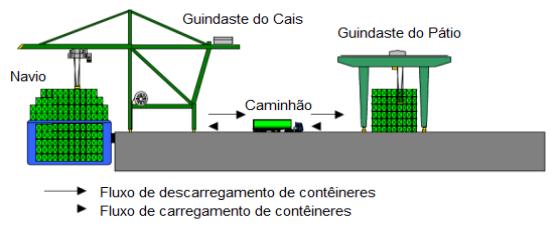

Figura 1. Movimentações de contêineres em um pátio portuário.

\section{Resultados e Discussão}

A representação por regras define como o pátio deverá ser carregado ou descarregado a cada intervalo de tempo, simulando as decisões tomadas e possibilitando uma melhor escolha dentre as opções fornecidas por este conjunto de regras. As regras de entrada são aquela que definem o modo com que os contêineres que estão chegando ao pátio portuário serão alocados, bem como sua ordenação, já as de saída referem-se a retirada de determinados contêineres e o novo rearranjo gerado por esta ação.

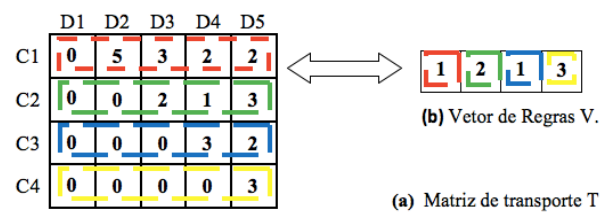

Figura 1. Relação da matriz de transporte $T$ com o vetor de Regras V.

Do funcionamento do algoritmo genético: inicialmente irá gerar os indivíduos aleatoriamente e avalia-los. Em seguida realiza as operações de seleção, cruzamento das melhores opções, manutenção dos melhores indivíduos das gerações anteriores e avaliação dos novos indivíduos. Assim, retorna o melhor valor encontrado para a função objetivo.

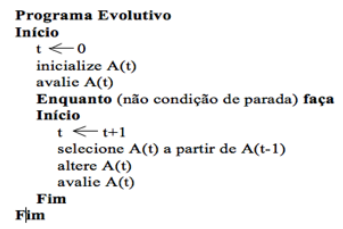

Figura 3. Estrutura Geral do Algoritmo Genético.

Os resultados foram obtidos a partir de testes que utilizam a matriz de transporte $\mathrm{T} e$ as regras de carregamento e descarregamento, variou-se as taxas de cruzamento e de mutação para avaliar a real influência destas para a eficiência do algoritmo genético.

As melhores opções apresentadas foram aquelas cuja probabilidade de Crossover é 0.8 e a probabilidade de mutação é 0.15 , com o número de movimentações igual a 52 .

\section{Conclusões}

O algoritmo genético é uma ferramenta que busca, seleciona e através de operadores genéticos, oferece a melhor ou melhores opções para uma determinada avaliação. Com a correta combinação de parâmetros é possível obter bons resultados a um tempo e custo computacionais aceitáveis. Os códigos empregados neste estudo foram satisfatórios e corresponderam ao esperado, uma vez que forneceram valores apropriados para comparação e estudo.

\section{Agradecimentos}

Agradeço ao professor, Anibal Tavares de Azevedo, pela orientação e pelos conhecimentos compartilhados durante o desenvolvimento do projeto.

\footnotetext{
${ }^{1}$ DEUS, N. M. R., AZEVEDO, A.T. Resolução do Problema de Carregamento e Descarregamento de Contêineres num Navio para Múltiplos Cenários via Representação por Regras e Algoritmo Genético. Universidade Estadual Paulista "Julio de Mesquita Filho", Guaratinguetá. FAPESP 2011. HOLLAND, J. H., Adaptation in natural and artificial systems. The University of Michigan Press, 1975. ${ }^{4}$ LINDEN, R. Algoritmos genéticos: Uma importante ferramenta da inteligência computacional. $2^{\mathrm{a}}$ edição. Rio de Janeiro: Brasport, 2008. ${ }^{5}$ MICHALEWICZ, Z. Genetic Algorithms + Data Structures = Evolution Programs, 3rd edition, Springer-Verlag, 1996.
} 